\title{
鉄筋コンクリート造耐震壁のせん断強度算定法に関する研究 A STUDY ON THE CALCULATION METHOD FOR THE SHEAR STRENGTH OF SHEAR WALLS
}

\author{
津田和 明*
}

Kazuaki TSUDA

\begin{abstract}
The calculation method for the shear strength of shear walls was shown in [Design Guidelines for Earthquake Resistant Reinforced Concrete Buildings Based on Inelastic Displacement Concept] published by ARCHITECTURAL INSTITUTE OF JAPAN (following, called AIJ equation). The calculated results by AJJ equation correspond with experiment results. But, the assumption that all horizontal bars in shear walls yield when shear walls reach at shear strength does not correspond with real phenomena. So, the new calculation method was developed. In the proposed method, the shear strength was determined with concrete compressive strength or horizontal bars yield strength. The calculation results by the proposed method corresponded better with experiment results than AIJ equation.
\end{abstract}

Keywords : shear wall, shear strength, truss theory, arch action 而震壁，せん断強度，トラス理論，アーチ機構

\section{1.はじめに}

鉄筋コンクリート造耐震壁のせん断強度算定式として，広沢式 ${ }^{1)}$ や日本建築学会の「鉄筋コンクリート造建物の勒性保証型耐震設計 指針・同解説」 ${ }^{2)}$ (以下, AIJ 勒性指針と称す) に示された式（以下， AIJ 指針式と称す) がよく用いられる。AIJ 指針式は，アーチ機構と トラス機構を仮定した半理論的な式であり, 実験結果と良い対応を 示す。一方，広沢式は数多くの実験結果の分析より導いた実験式で あるが，コンクリートの負担分と壁板横筋による負担を区分してお り，前者がアーチ機構，後者がトラス機構とみなすことができる。 この式は AIJ 指針式と同様に十分な精度を有している。

これらの算定式では，簡便性を優先させ，基本的に壁板の全横筋 が降伏することを前提としている。AIJ 指針式では, トラス機構に おいては壁板横筋降伏前にコンクリートが先行して圧壊しないこと が条件となっており，この条件を満足する場合はトラス機構で釣り 合うコンクリート圧縮応力度を算定し, 有効圧縮強度からそれを減 算したものがアーチ機構で用いられる。この際，これに釣り合う鉛 直方向の引張材は側柱主筋であるとし, 側柱主筋は一様応力状態で 弾性であると仮定している。この手法は，柱，梁においても同様で あり, アーチ機構はせん断補強筋が関与せず, 部材端部のせい方向
の拘束力と主筋の一様引張応力とコンクリート圧縮ストラットの圧 縮応力が釣り合うと仮定している。

柱，梁において，このアーチ機構を再現すべく，種々の実験や解

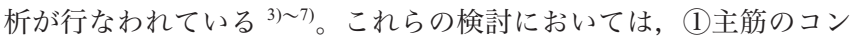
クリートとの付着の除去, (2)せん断補強筋なし, もしくは, 両者と も施している。白石らは，検討の結果，AIJ 指針式におけるアーチ 機構の圧縮ストラットの形状を形成するためには，せん断補強筋が 存在せず，主筋の付着が期待できる場合である可能性が高いと報告 している7)。このとは, AIJ 指針式におけるアーチ機構のメカニズ ムが存在しない可能性が高いことを示唆している。さらに, 白石ら は，この場合のせん断抵抗を可能としているのは，かぶりコンクリ ート部分の曲げ抵抗がせん断補強筋と同様な効果をもたらしている ことに起因すると記述している。

筆者は，鉄筋コンクリート造の耐震壁において，せん断ひびわれ 後のせん断力〜せん断変形関係の算定法としてトラス剛性法が有効 であり，この際，側柱による水平方向の拘束効果を考慮することが 必要であることを報告した $\left.{ }^{8)}, 9\right)$ 。の拘束効果には，側柱の曲げ抵 抗を仮定しており，白石らの検討結果と対応する。この考え方に基 づく耐震壁のせん断強度算定法が考案できれば，実際の抵抗機構に より近接した算定法となるものと思われ，その検討を試みることに

\footnotetext{
$*$ 大林組技術研究所 主任研究員 $\cdot$ 博士 $($ 工学 $)$
}

Technical Research Institute, Obayashi Corporation, Dr. Eng. 
した。本報では，現段階での検討結果をまとめた。

\section{2. 本提案手法の概要}

基本的に, 耐震壁のせん断抵抗機構として, 図 1 に示すトラス抵 抗機構を仮定する ${ }^{8)}$ ，99。これは，コンクリートの斜め圧縮バネと鉛 直方向と水平方向の引張バネにより構成される。鉛直バネは側柱の 主筋と壁板の縦筋, 水平バネは壁板横筋と側柱による曲げ抵抗バネ により形成される。そして, これらのバネのいずれかが, 強度に達 した時を耐震壁のせん断強度とする。ただし, 鉛直方向に関しては, 曲げに支配されると考え, ここでは, 式(1)に示す通り, コンクリー 卜斜め圧縮バネと水平方向バネの強度によって, せん断強度を決定 する。以下, 式中の記号の単位は SI 単位系であり, 力は $\mathrm{N}$, 距離は $\mathrm{mm}$ である。

$$
Q_{s u}=\min \left(Q_{c c}, Q_{h y}\right)
$$

上式中, $Q_{c c}$ はコンクリートの斜め圧縮バネの強度で決定されるせ 几断強度であり, 式(2)で表される。

$$
Q_{c c}=\tau_{c c} \ell_{a} t_{w}=\frac{\sigma_{2} \sin 2 \theta}{2} \ell_{a} t_{w}=\frac{v \sigma_{B} \sin 2 \theta}{2} \ell_{a} t_{w}(2)
$$

この強度は, 図 2 のうに耐震壁脚部で決定する。上式は, コン クリートの有効圧縮強度を一軸圧縮強度 $\left(\sigma_{B}\right.$ : 正值)に有効圧縮強 度係数（ 2 ）を乗じた值とし，これをコンクリートの最小主応力度 $\left(\sigma_{2}\right)$ とし, 最大主応力度をゼロとすることによって, 主応力度式 よりせん断応力度 $\left(\tau_{c c}\right)$ を求め, これに耐震壁脚部の有効断面積 (有効長さ $: \ell_{a}$, 壁厚 $: t_{w}$ ) 乗じてせん断強度を算定している。主圧 縮方向角度 $(\theta$ : 縦軸より反時計回り $)$ の算定方法は後述する。コン クリートの有効圧縮強度係数（ 2 ）は, 式(3)のように圧縮強度に応 じて, Nielsenの下限式 ${ }^{10)} と \mathrm{CEB}$ 式 ${ }^{11)}$ にり算定する。

$$
v=\left(\begin{array}{ll}
0.7-\frac{\sigma_{B}}{200} & \sigma_{B} \leq 45 \mathrm{~N} / \mathrm{mm}^{2} \\
1.698 \sigma_{B}{ }^{-0.333} & \sigma_{B}>45 \mathrm{~N} / \mathrm{mm}^{2}
\end{array}\right.
$$

耐震壁脚部の有効壁長さ $\left(\ell_{a}\right)$ は, 式(4)で求めることにした。式 中， $\ell_{w}$ は両側柱の芯々間距離， $D_{c}$ は側柱せいである。 $h_{a}$ は，コンク リート圧縮ストラットの引張縁での最下端の耐震壁脚部からの高さ を表したものである。これは, 耐震壁のある高さ位置において, 単 位面積当りのコンクリート圧縮ストラットの水平成分の剛性とその 位置での水平抵抗バネの剛性を比較し, 水平抵抗バネ剛性の方が大 きければ，その高さ位置では，引張縁からコンクリートの圧縮力伝 達が可能と考えた。つまり, 最下端位置では, 単位面積当りのコン クリート圧縮ストラットの水平成分の剛性と水平抵抗バネ剛性が一 致することになる。

図 3 のように, 耐震壁引張縁の耐震壁脚部から $x$ の位置において 鉛直方向の単位面積に $P$ という水平力が作用すると仮定すると, そ の主圧縮方向の成分は $P / \sin \theta$, 圧縮応力度は $\sigma=P / \sin ^{2} \theta$,

これによる圧縮ひずみ度は $\varepsilon=\sigma / K_{2} \quad\left(K_{2}:\right.$ コンクリート圧縮ス トラットの単位面積当りの剛性), 縮み量は $\delta=\varepsilon x / \cos \theta$, この水
平成分は $\delta_{x}=\delta / \sin \theta$ であるから, この水平方向の剛性は $K_{c}=P / \delta_{x}=K_{2} \cos \theta \sin ^{3} \theta / x$ となる。これに対し, 耐震壁 の水平方向抵抗バネ剛性は, 本来高さ方向で変動するものであるが, ここでは計算の煩雑さを避けるため, 単位面積当りの平均バネ剛性 $K_{x}$ を用いると, $K_{h}=2 K_{x} / \ell_{w}$ となる。よって，これらの剛性が 一致する時の高さ $h_{a}$ は, 式(5)より求められる。

$$
\ell_{a}=\ell_{w}+D_{c}-h_{a} \tan \theta
$$

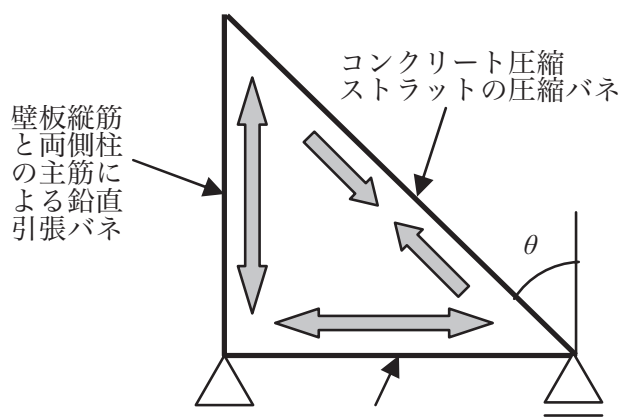

壁板横筋と両側柱の曲げ 抵抗による水平引張バネ

図 1 本堤案手法におけるトラス機構の概念
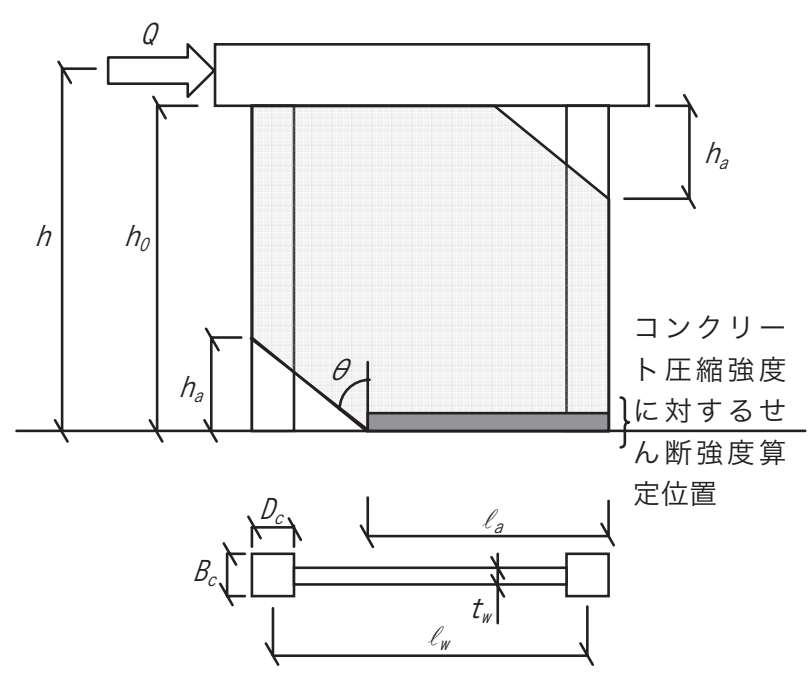

定位置

図 2 耐震壁各部の記号

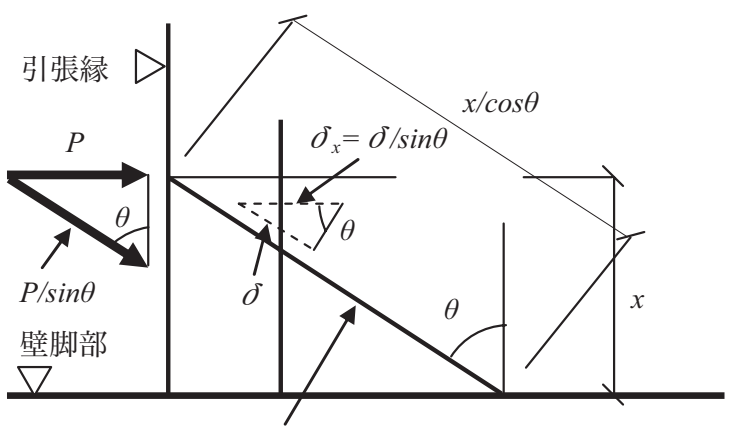

単位面積当りのコンクリート圧縮ストラット

図 $3 h_{a}$ 算定手法の概念 


$$
h_{a}=\frac{K_{2} \cos \theta \sin ^{3} \theta}{\frac{2 K_{x}}{\ell_{w}}}
$$

上式は, 水平方向の単位面積当りの平均バネ剛性 $K_{x}$ を用いている こと, また, 別の要因で $h_{a}$ が定まる可能性もあり, 妥当な解が得ら れない可能性がある。これに関しては「3．ha制限値」に記述し ているように， $h_{a}$ に制限值を設けて対応することにした。

次に, $Q_{h y}$ についてまとめる。 $Q_{h y}$ は壁板横筋が降伏する時のせん 断強度である。このことから, 本提案手法では, 壁板横筋が存在し ない耐震壁は対象外となる。 $Q_{h y}$ は式(6)より算定される。

$$
\begin{aligned}
Q_{h y} & =\tau_{h y}\left(\ell_{w}+D_{c}\right) t_{w}=\frac{\sigma_{x}}{\tan \theta}\left(\ell_{w}+D_{c}\right) t_{w} \\
& =\frac{\sigma_{h y} K_{x}}{E_{h s} \tan \theta}\left(\ell_{w}+D_{c}\right) t_{w}
\end{aligned}
$$

上式は, 水平方向応力度 $\left(\sigma_{x}\right)$ を壁板横筋の降伏ひずみ度 $\left(\sigma_{h y} / E_{h s}\right.$, $\sigma_{h y}$ : 壁板横筋降伏強度) に水平方向の単位面積当りの平均バネ剛 性 $K_{x}$ を乗じた值とし, 主応力度式よりこの時のせん断応力度 $\left(\tau_{h y}\right)$ を求め, 壁板全長と壁厚を乗じてせん断強度を算定している。壁板 全長を用いたのは, 殆どの壁板横筋が降伏するような耐震壁では, 壁板の応力状態がほぼ均一と見なせると判断したためである。

ここで, 主圧縮方向角度 $(\theta)$ の算定方法について記述する。主圧 縮方向角度は, 式(7)より算定する。

$$
\left(\frac{1}{K_{x}}-\frac{1}{K_{y}}\right) \cos ^{4} \theta-2\left(\frac{1}{K_{2}}+\frac{1}{K_{x}}\right) \cos ^{2} \theta+\frac{1}{K_{2}}+\frac{1}{K_{x}}=0 \text { (7) }
$$

上式は, 最小ポテンシャルエネルギーの原理に従って主圧縮方向 角度を求める式であり, この式より求めた角度, 及びこの角度を用 いて算定するせん断ひびわ机後のせん断力〜せん断変形関係が実験 結果と良い対応を示すことは，既報で報告している ${ }^{8), 99 。 ~}$

水平方向, 鉛直方向の単位面積当りの平均バネ剛性 $K_{x}, K_{y}$ は既報 と同じであり，それぞれ式(8)，(9)で算定する。

$$
\begin{aligned}
& K_{x}=K_{f}+p_{w h} E_{h s}=\frac{360 E_{c} I_{c} \ell_{w}}{t_{w} h_{0}^{4}}+p_{w h} E_{h s} \\
& K_{y}=2 p_{c g d} E_{c s}+p_{w v d} E_{v s}
\end{aligned}
$$

式(8)中の $K_{f}$ は, 側柱の曲げ抵抗による水平抵抗バネ剛性である。 この式は, 引張側, 圧縮側の柱が同様に変形すると仮定し, それら が等分布荷重を受ける両端固定梁 (スパン長 $=$ 耐震壁内法高さ $: h_{0}$ ) とみなした場合の平均たわみ量を両側柱芯々間距離で除すことによ り求めた。式中, $E_{c}$ はコンクリートのヤング係数, $I_{c}$ は側柱の断面 二次モーメント, $p_{w h}$ は壁板横筋比, $E_{h s}, E_{v s}, E_{c s}$ は壁板横筋, 縦筋 および側柱主筋のヤング係数である。

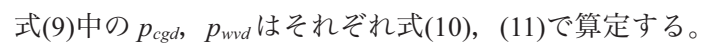

$$
p_{c g d}=\frac{p_{c g} B_{c} D_{c}}{\left(\ell_{w}+D_{c}\right) t_{w}}
$$

$$
p_{w v d}=\frac{p_{w v}\left(\ell_{w}-D_{c}\right)}{\ell_{w}+D_{c}}
$$

上式中, $p_{c g}, p_{w v}$ は側柱主筋比と壁板縦筋比, $B_{c}$ は側柱幅である。 コンクリートの斜め圧縮方向のバネ剛性 $\left(K_{2}\right)$ に関しては, ここ では終局状態をターゲットとしていることから, 既報のものに補正 係数を乗じることにした。補正係数は, 圧縮強度時のひずみ度が, $\sigma_{B}=20 \mathrm{~N} / \mathrm{mm}^{2}$ 時で $\varepsilon_{B}=1600 \mu, \sigma_{B}=120 \mathrm{~N} / \mathrm{mm}^{2}$ 時で $\varepsilon_{B}=5000 \mu$ 程度とな るように設定した $\left(\sigma_{B}=45 \mathrm{~N} / \mathrm{mm}^{2}\right.$ 時で $\varepsilon_{B}=2500 \mu$ 程度 $)$ 。

補正係数を乗じたコンクリートの斜め圧縮方向のバネ剛性 $\left(K_{2}\right)$ の算定式を式(12)に示す。

$$
K_{2}=0.168 \sigma_{B}^{0.38} E_{c} \frac{1}{0.01 \sigma_{B}+0.8}
$$

\section{3. $h_{a}$ の制限值}

前述したように, 耐震壁引張縁における圧縮ストラット最下端の 耐震壁脚部からの距離を表す $h_{a}$ には制限值を設ける必要があると 予想された。そこで, 既往の耐震壁実験結果に本提案手法を適用し,

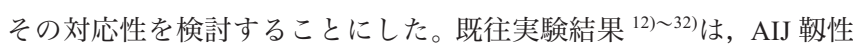
指針において精度検証に用いた 1 層モデルの試験体（計 108 体）と 基本的には同じであるが, 計算せん断強度よりも計算曲げ強度が低 いにも係わらず，計算曲げ強度が実験最大耐力の 1.5 倍以上となる 試験体と壁板横筋比がゼロである試験体は除去した。前者の試験体 は, 文献 21）のW2-3, W2-4 試験体であり, これらに関しては筆者 が載荷システムを明確に理解できていないものと思われる。また後 者の試験体は, 文献 18）の CW-0.6-0-0, CW-0.6-0-20, CW-06-0-40 試験体である。これらの試験体を省いた結果, 検討対象に用いた試 験体数は 103 体となった。

これら既往実験結果と式(13)による曲げ強度と本提案手法による せん断強度の小さい方の值と比較した結果, 平均 1.28 , 変動係数 3.427 であり, かなり精度が悪いことが分かった。個々の試験体と の対応性をみると, 著しく対応が悪いのは, 文献 25)の W08, W12 試験体と文献 26)，27)の NW-1 6 試験体の計 8 体であり, 基本的に シアスパン比が大きい, 壁板横筋比が小さいなどにより, 水平方向

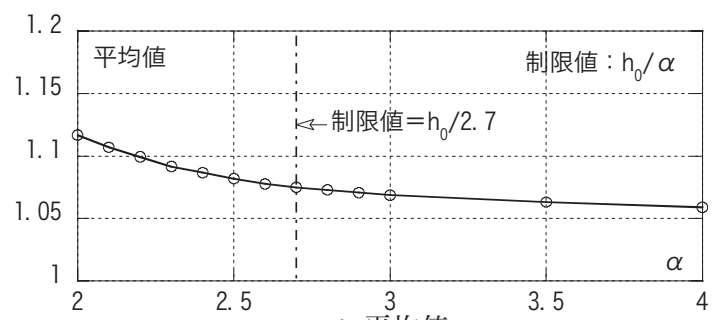

a) 平均値

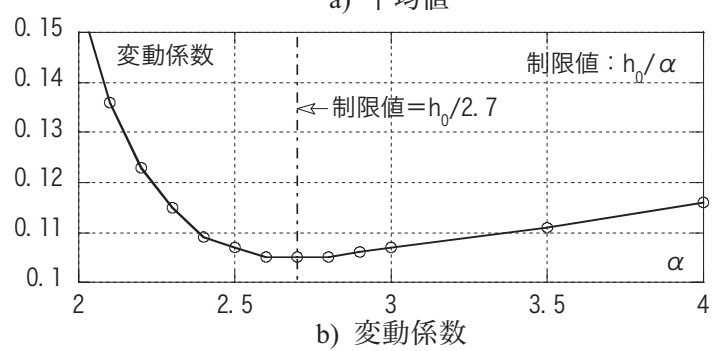

図4 制限值と平均值, 変動係数との関係 
バネ剛性が鉛直方向バネ剛性とコンクリートの斜め圧縮バネ剛性に 比べ著しく小さい場合であり, 本提案手法によるせん断強度が実験 值に比べ著しく小さい $\left(h_{a}\right.$ が著しく大きい)。これら対応の悪い試験 体を省くと, 平均 1.08 , 変動係数 0.110 であり, 良い対応を示した。 対応の悪い実験結果も含めて, ある程度の精度を確保するため, 種々 の検討を行った。一つには, ここに示した水平方向の剛性の釣り合 い以外に，この釣り合い機構における側柱の曲げ強度（内法高さ中 央での曲げ降伏を想定）やせん断強度等を検討したが，精度はさほ ど向上しなかった。そこで, ここでは, 暫定処置として $h_{a}$ に制限值 を設けることにした。制限值は, 103 体の既往実験結果に対する変 動係数が最も小さくなる時とした。制限值と平均値, 変動係数との 関係を図 4 に示す。これらの図より, 変動係数が最も小さくなるの は，制限值を $h_{0} / 2.7$ とした時であることが分かる。よって，暫定処 置として，制限值を式(14)のように定める。

$$
Q_{f u}=\frac{a_{g} \sigma_{c y} \ell_{w}+0.5 a_{w v} \sigma_{v y} \ell_{w}+0.5 N \ell_{w}}{h}
$$

$$
h_{a} \leq \frac{h_{0}}{2.7}
$$

式(13)中, $a_{g}, a_{w v}$ は引張側柱全主筋断面積, 壁板全縦筋断面積, $\sigma_{c y}$, $\sigma_{v y}$ は引張側柱主筋と壁板縦筋の降伏強度, $N$ は軸方向力 (圧縮を正), $h$ は加力高さである。

\section{4。既往実験結果を用いた本堤案手法の精度検証}

ここでは，既往実験結果を用いた本提案手法の算定精度の検証に 関してまとめる。用いた既往実験結果は，前項と同じものである。 比較として AIJ 指針式と広沢式による算定結果も示した。それらの 式をそれぞれ式(15)，(16)に示す。下式中， $\ell_{w b} ， \ell_{w a}$ はトラスとアー チ機構の有効壁長さ， $\beta$ はトラス機構によるコンクリート圧縮応力 度と有効圧縮強度の比， $\phi, \theta_{a}$ はトラスとアーチ機構の圧縮ストラ ット角度である。 $p_{c g}$ は側柱主筋比 $(\%), \sigma_{0}$ は軸方向応力度（圧縮 を正), $b_{e}$ は等価壁厚， $\ell_{a w}$ は壁全長， $j$ は応力中心間距離である。

$Q_{a i j}=t_{w} \ell_{w b} p_{w h} \sigma_{w y} \cot \phi+\tan \theta_{a}(1-\beta) t_{w} \ell_{w a} v \sigma_{B} / 2(15)$
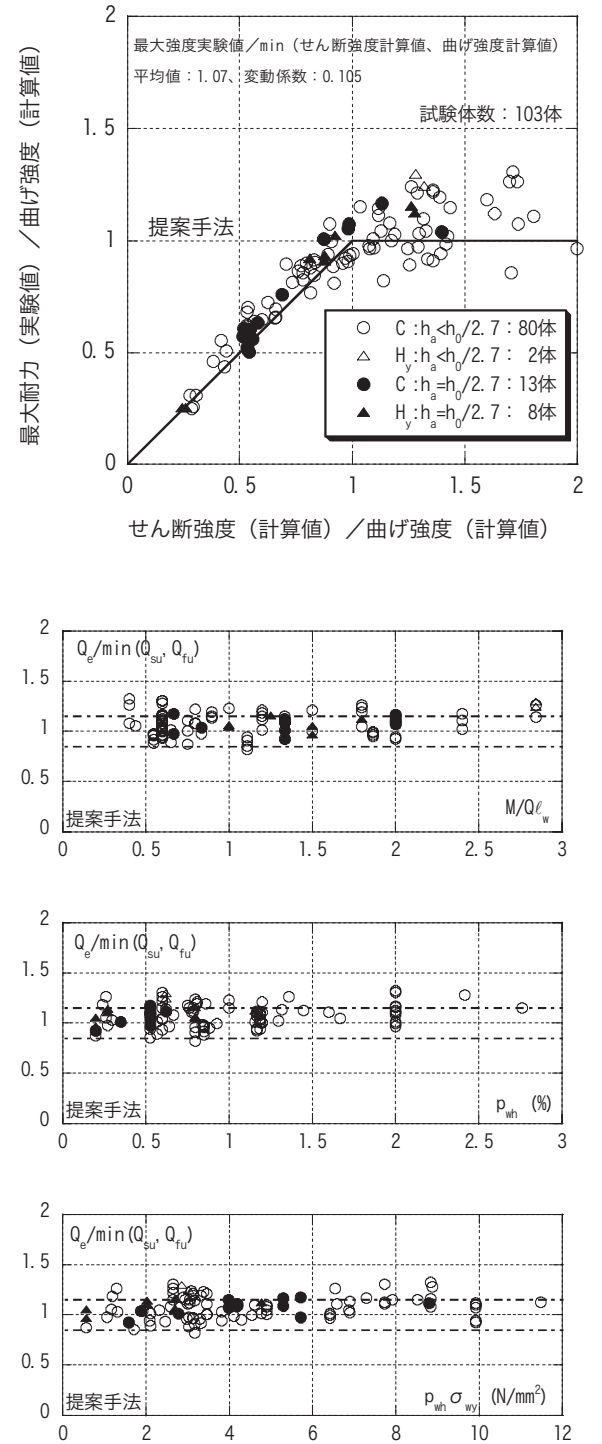
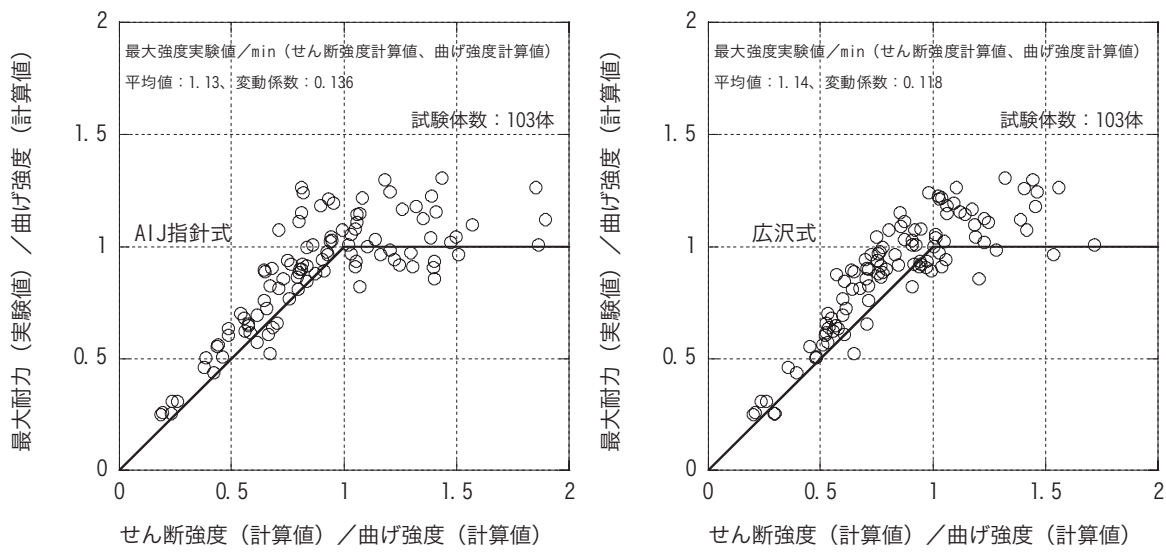

図 5 各算定式の精度

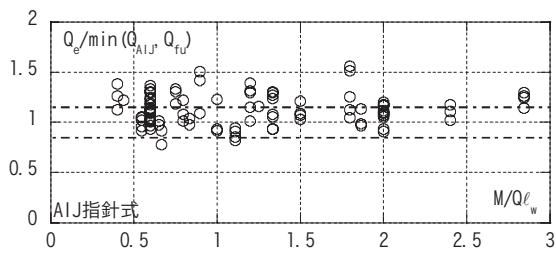

a) シアスパン比

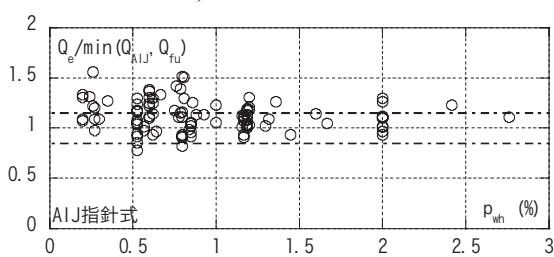

b) 壁板横筋比
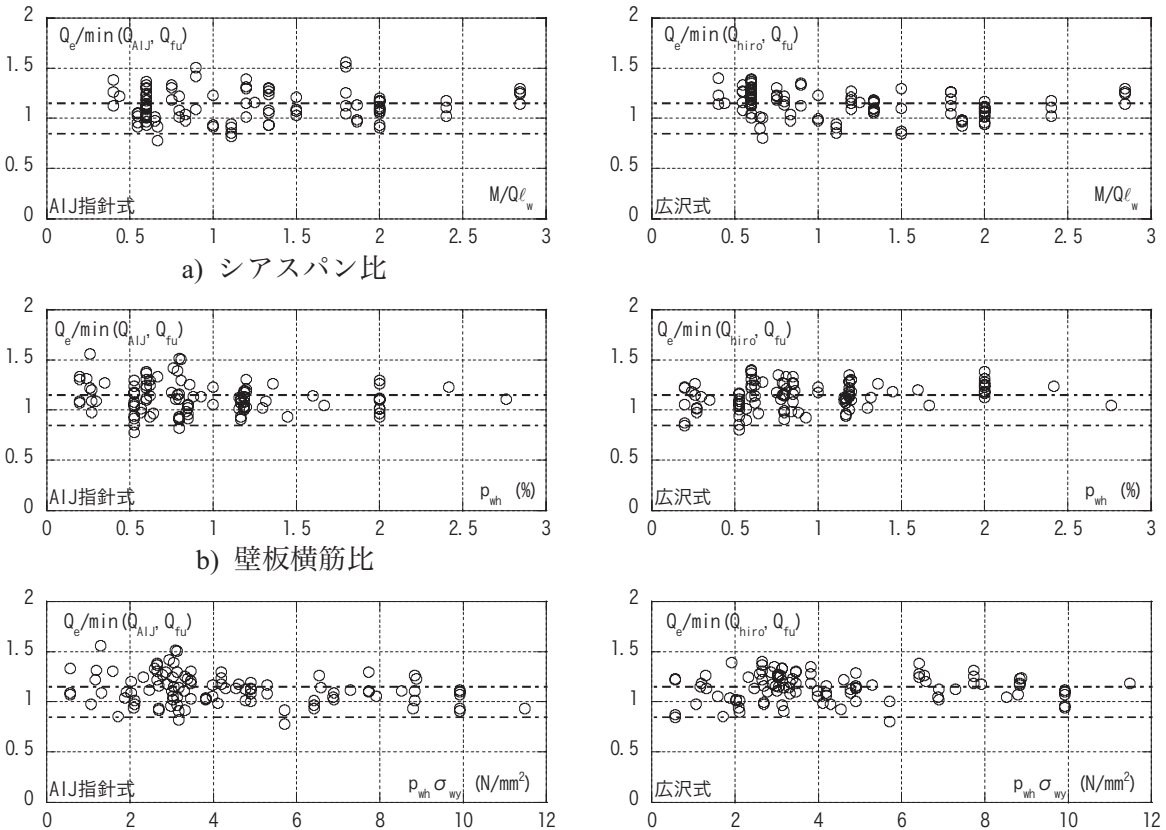

c) 壁板横補強強度

図 6 各算定式の要因分析 -1 

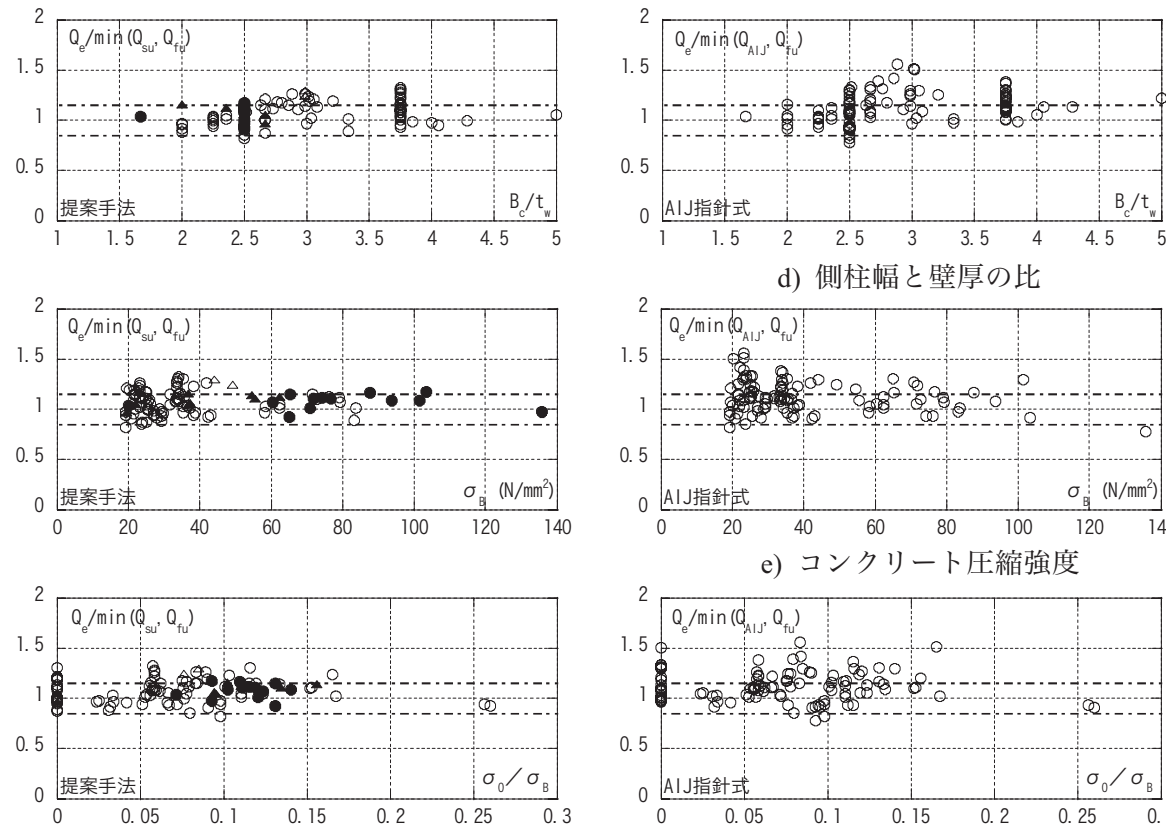

d) 側柱幅と壁厚の比

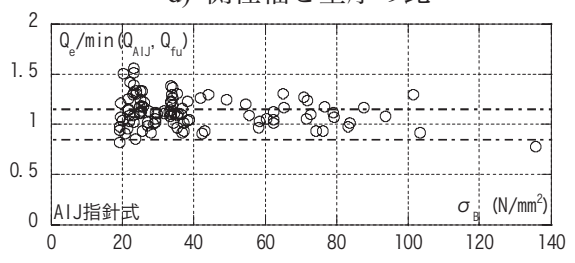

e) コンクリート圧縮強度

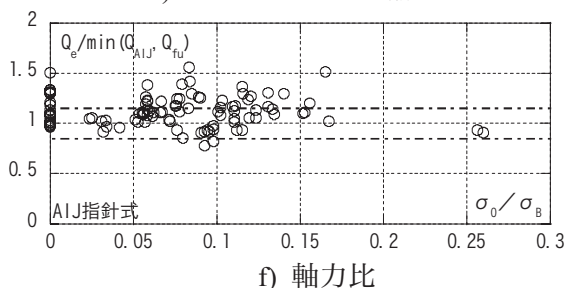

図 7 各算定式の要因分析 -2
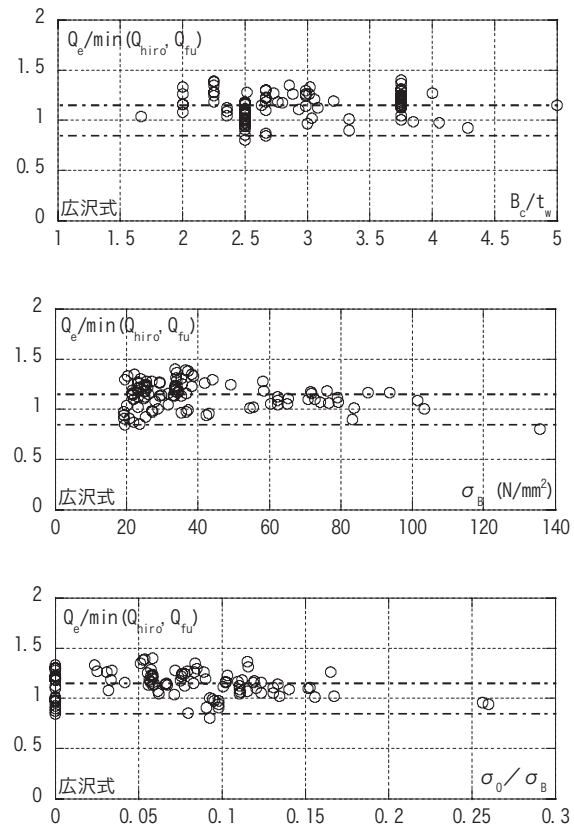

$$
Q_{\text {hiro }}=\left\{\begin{array}{l}
\frac{0.068 p_{c g}{ }^{0.23}\left(\sigma_{B}+17.6\right)}{\sqrt{M /\left(Q \ell_{a w}\right)}} \\
+0.85 \sqrt{p_{w h} \sigma_{h y}}+0.1 \sigma_{0}
\end{array}\right\} \times b_{e} j
$$

本堤案手法, AIJ 指針式, 広沢式の既往実験結果との比較を図 5 に示す。これらの図は, 縦軸に実験による最大耐力, 横軸に計算せ 几断強度を, それぞれ式(13)で求めた曲げ強度計算值で除して表し た。本堤案手法では, 最大強度決定要因 $(C$ : コンクリート圧縮ス トラットの圧壊で決定, $H_{y}$ : 壁板横筋の降伏で決定） 值に達したか否かで記号を分けた。強度比の平均值, 変動係数は, 本堤案手法が $1.07,0.105$, AIJ 指針式が 1.13, 0.136, 広沢式が 1.14 , 0.118 であり, 僅かではあるが, 本堤案手法が最も精度が良い。また, 強度比が 1.0 を下回る試験体数は, 全試験体 103 体中, 本提案手法 が 30 体, AIJ 指針式が 21 体であるが, 強度比の最小值は, 本堤案 手法が 0.82, AIJ 指針式が 0.78 であることから, 設計で本堤案手法 を用いる場合には AIJ 指針式と同等の安全率を設定すれば良いと考 える。なお，本堤案手法において， $h_{a}$ が制限值に達した試験体は 103 体中, 21 体であった。

さらに, シアスパン比 $\left(M / Q \ell_{w}\right)$, 壁板横筋比 $\left(p_{w h}\right)$, 壁板横補強 強度 (横筋比 $\times$ 降伏強度 : $\left.p_{w h} \sigma_{w y}\right)$, 側柱幅と壁厚の比 $\left(B_{c} / t_{w}\right)$, コ ンクリート压縮強度 $\left(\sigma_{B}\right)$, 軸力比 (軸応力度は全水平断面積に対 する值： $\sigma_{0} / \sigma_{B}$ ) に対する計算精度の変動傾向を検討した。それら の実験最大耐力と計算の曲げ強度とせん断強度の小さい方との比と の関係を図 $6 ， 7$ に示す。図中， $\pm 15 \%$ の横線を示した。

シアスパン比に関しては, 3 手法とも, シアスパン比が 2 より大 きくなると, やや強度比が大きくなる傾向を示す。この值は, 3 手 法とも曲げ強度で決定しているため, 全く同じ值となっている。壁 板横筋比に対しては, 本提案手法が壁板横筋比の増大に伴い, 強度 比も若干大きくなる傾向を示している。しかし， $p_{w h}=2.75 \%$ の場合
でも, 強度比は 1.15 程度であり, 精度としては十分であると考える。 AIJ 指針式，広沢式は，試験体数の多い $p_{w h}=0.5 \sim 1.0 \%$ の場合に， バラツキが大きくなっている。壁板横補強強度に対しては， 3 手法 とも大きな差はなく, 偏りも見られない。側柱幅と壁厚の比に対し ては, 3 手法とも大きな偏りは見られないが, AIJ 指針式では $B_{c} / t_{w}=3$ 前後においてややバラッキが大きい。コンクリート圧縮強度に対し ては, 試験体数が多い $\sigma_{B}=20 \sim 40 \mathrm{~N} / \mathrm{mm}^{2}$ において, 3 手法とも他の 強度帯に比べややバラッキが大きい。軸力比に対しては，唯一軸力 を考慮している広沢式では，軸力が載荷されているほとんどの試験 体の強度比が 1.0 以上となっている。他の 2 手法に関しては，大き な偏りは見られない。

強度比に関して要因分析を行なった結果，本提案手法は耐震壁を 構成する各要因に対して, 特に問題となるような偏りはなく, 基本 的に AIJ 指針式，広沢式と同様な傾向を示した。

\section{5. 既往 FEM 解析結果を用いた本堤案手法の精度検証}

ここでは, 長沼が実施した FEM 解析による耐震壁のパラメトリッ

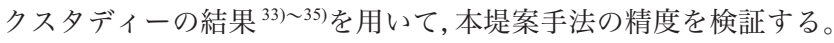
長沼は 100 体を越える実験結果を用いて FEM 解析手法の精度検証 を実施した上でパラメトリックスタディーを行なっており，この解 析結果は十分に信頼するに值すると判断した。長沼は, シアスパン 比を $0.42 〜 2.79$, 壁板鉄筋比（縦横同一）を $0.0 〜 2.32 \%$ (ここでの 検討対象範囲は $0.32 \sim 2.32 \%$ ), 側柱主筋比を $0.84 \sim 10.0 \%$ ( $5.44 \%$ 以 上で強度がほぼ一定と記載）まで変化させて，耐震壁のせん断強度 の変動傾向を検討している。耐震壁の平面形状は, 側柱芯々間距離 が $8000 \mathrm{~mm}$, 壁厚 $200 \mathrm{~mm}$ ，側柱は $850 \mathrm{~mm}$ 角であり，上部梁は剛に 近いものとしている。材料強度は，コンクリートが $\sigma_{B}=24 \mathrm{~N} / \mathrm{mm}^{2}$, 壁板の鉄筋が $\sigma_{y}=300 \mathrm{~N} / \mathrm{mm}^{2}$ であり，側柱主筋は弾性としている。

ここでは, シアスパン比 $\left(M / Q \ell_{w}\right)$, 壁板鉄筋量 $\left(p_{w}\right)$, 側柱主筋量 $\left(p_{c g}\right)$ に対するせん断強度の変動傾向に関して検討した。 

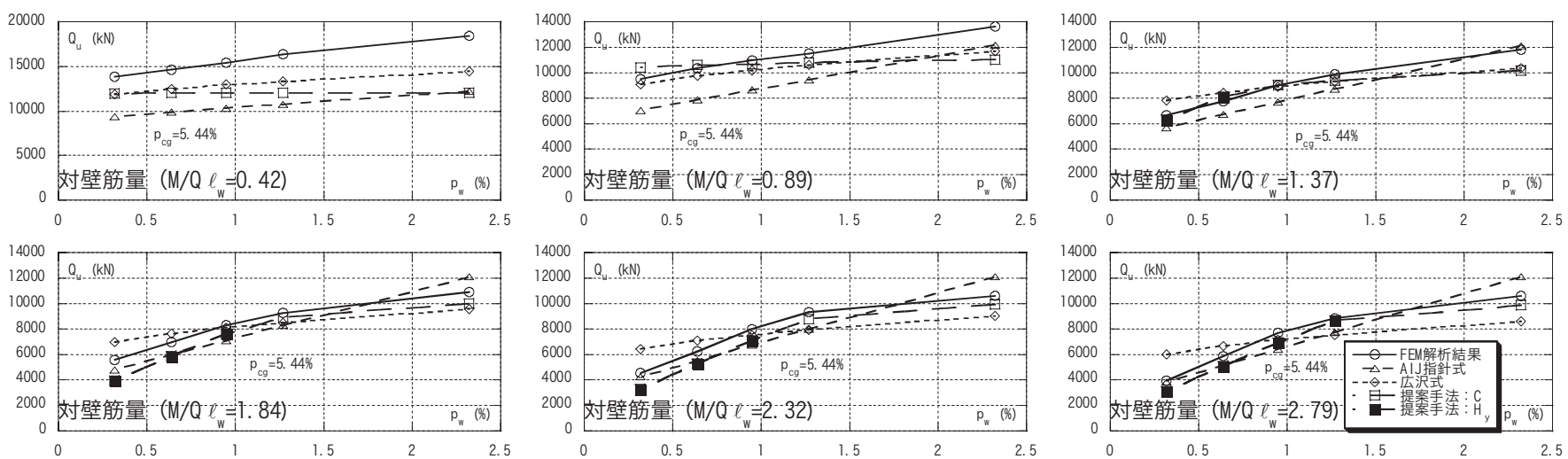

図 8 FEM 解析結果との比較 (対壁筋量)
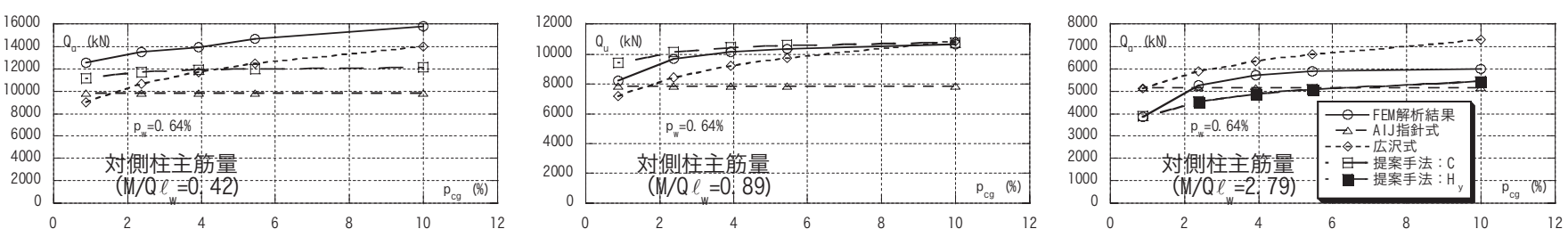

図 9 FEM 解析結果との比較 (対側柱主筋量)

壁板鉄筋量とせん断強度関係の比較を図 8 に, 側柱主筋量とせん 断強度関係の比較を図 9 にそれぞれシアスパン比ごとに示す。本提 案手法の場合は, 強度決定要因で記号を分けた。また, $h_{a}$ が制限值 に達した解析ケースは, $M / Q \ell_{w}=1.37$ で $p_{w}=0.32 \%$ と, $M / Q \ell_{w}=1.84$ で $p_{w}=0.32 \%$ の 2 ケースだけであった。

壁板鉄筋量に対する変動傾向（側柱主筋量 : $p_{c g}=5.44 \%$ ）を見る と, $M / Q \ell_{w}=0.42$ の場合, FEM 解析結果が最も大きく, 壁板鉄筋量 にほぼ比例してせん断強度は増大する。これとほぼ同様な傾向を示 したのは, AIJ 指針式と広沢式であった。本堤案手法では $p_{w}=0.32 \%$ の場合において壁板の圧縮ストラットは壁板のほぼ全域を占めてい るため (壁板全長 $8850 \mathrm{~mm}$ に対し, 水平有効長さは $\ell_{a}=8770 \mathrm{~mm}$ ), 以降，壁板鉄筋比を増やしてもせん断強度はほとんど増大しない。

$M / Q \ell_{w}=0.89$ の場合も 0.42 の場合とほぼ同様な傾向であるが, FEM 解析結果と各算定式の結果の差は小さくなっている。 $M / Q \ell_{w}=1.37$ 以上では, FEM 解析による結果は, $p_{w}=1.27 \%$ を境に増大率が鈍化 する。この傾向を最も良く表しているのは本提案手法であり, せん 断強度は壁板鉄筋量が小さい時は壁板鉄筋の降伏で, 大きい場合は コンクリート圧縮ストラットの圧壊で決定している。

一方, 側柱主筋量に対する変動傾向（壁板鉄筋量 : $p_{w}=0.64 \%$ ）を 見ると, $M / Q \ell_{w}=0.42$ の場合, FEM 解析結果が最も大きく, 側柱主 筋量にほぼ比例してせん断強度は増大する。この傾向を最も良く表 しているのは，広沢式であった。AIJ 指針式は側柱主筋量をパラメ ータとして考慮していないため, 水平に推移する。 $M / Q \ell_{w}=0.89$ と 2.79 の場合, FEM 解析結果は $p_{c g}=2.39 \%$ で増大率は鈍化し, $p_{c g}$ $=3.92 \%$ 以降はほとんど変動しない。この変動傾向を最も良く表して いたのは，本提案手法であった。

また, 壁板鉄筋量が $p_{w}=0.64 \%$ 以下, 側柱主筋量が $p_{c g}=0.89 \%$ の場 合は，3 算定式による結果は FEM 解析結果を上回る場合があり， 注意を要する。特に，広沢式による結果は $M / Q \ell_{w}=2.79, p_{w}=0.64 \%$ で側柱主筋量が変動する場合, 常に FEM 解析結果を上回っている。
本提案手法で FEM 解析結果を最も大きく上回ったのは, $M / Q \ell_{w}$ $=0.89, p_{w}=0.64 \%, p_{c g}=0.89 \%$ の場合で, その強度比（FEM 解析結 果／提案手法算定結果）は 0.87 であった。

FEM 解析結果を用いて本堤案手法の算定精度を検証した結果, シア スパン比が小さい場合は，本堤案手法によるせん断強度は壁板鉄筋 量や側柱主筋量を増大してもほとんど変動せず, FEM 解析結果と異 なる傾向を示したが，シアスパン比の増大とともに，本堤案手法に よる結果は FEM 解析結果と近似した変動傾向を示した。シアスパ ン比が小さい場合には，壁板鉄筋比が小さい場合でも圧縮ストラッ トはほぼ壁板全域を占めていることから，圧縮側柱の負担せん断力 を考慮する必要があると思わ机る。

\section{6. まとめ}

既に提案している耐震壁のせん断ひびわれ後のせん断力〜せん断 変形関係を求めるのに用いるトラス剛性法（側柱による曲げ抵抗を 壁板横筋の伸び進展の拘束効果として考慮）に基づくせん断強度算 定法を提案した。

この提案手法は, 壁板の圧縮ストラットの領域算定において, 暫 定的に制限值を設けているが, 既往実験結果, FEM 解析結果を用い て算定精度を検証した結果，AIJ 指針式，広沢式と同等以上の精度 を有することが分かった。また，せん断力に対する抵抗機構に着眼 して, 耐震壁のせん断強度算定法の検討を行った結果, 外周フレー ムによる拘束効果の反映が肝要であることが分かった。

今後の改良項目としては，以下のことが考えられる。

1 ）圧縮ストラットの領域算定における制限值の撤廃。

2 ）壁板横筋比が存在しない場合の対応。

3 ) 軸方向力の考慮。特に引張軸力作用時。

4 ）圧縮側柱の負担せん断力の考慮。

5 ）開口耐震壁への拡張。

6 ）連層耐震壁への拡張。 
「圧縮ストラットの領域算定における制限值の撤廃」に関しては, コンクリート压縮ストラットの引張縁での最下端の耐震壁脚部から の高さ $\left(h_{a}\right)$ の意味合いを考えた上で検討したい。

\section{参考文献}

1) 日本建築学会: 建築耐震設計における保有水平耐力と変形性能 (1990), 1990.10

2) 日本建築学会 : 鉄筋コンクリート造建物の勒性保証型耐震設計指針・同 解説, 1999.8

3) 滝口克己, 藤山淳司 $: \mathrm{R} / \mathrm{C}$ 柱部材のアーチ機構による終局せん断耐力に 関する研究, 日本建築学会構造系論文集, 第 503 号, pp. $93 \sim 100,1998.1$

4) 浜原将之, 他 3 名: コンクリート系部材のアーチ作用によるせん断伝達 機構に関する研究, コンクリート工学年次論文集, Vol.22, No.3, pp.655 $\sim 660,2000$

5) 村上 聖：鉄筋コンクリート梁の終局せん断強度算定式に関する一考察, 日本建築学会構造系論文集，第 533 号，pp.143〜 150，2000.7

6) 瀧口克己, 西村康志郎 : せん断補強筋のない $\mathrm{RC}$ 柱部材の斜め圧縮力伝 達能力, 日本建築学会構造系論文集, 第 534 号, pp.113 119, 2000.8

7) 白石一郎, 他 2 名: 主筋付着の有無が RC 柱のせん断挙動に及ぼす影響, コンクリート工学年次論文集，Vol.24，No.2，pp. 871～876， 2002

8) 津田和明 : 面内せん断力を受ける平板のせん断応力度〜せん断ひずみ度 関係の算定法, 日本建築学会構造系論文集, 第 517 号, pp.125～132, 1999.3

9) 津田和明，江戸宏彰 : 鉄筋コンクリート造連層耐震壁の復元力特性（又 ケルトンカーブ）の算定法 - 鉄筋コンクリート造連層耐震壁の性 能評価手法に関する研究（その1） -, 日本建築学会構造系論文集, 第 569 号, pp. $97 \sim 104,2003.7$

10) Nielsen, M.P. : Limit Analysis and Concrete Plasticity, Prentice-Hall, 420p., 1984

11) COMIT EURO-INTERNATIONAL DU BETON : CEB-FIP MODEL CODE FOR CONCRETE STRUCTURE, 1978

12) 青山博之, 他 2 名 : 増設 RC 耐震壁の耐力と変形能の評価に関する実験 的研究 (その 1 , その 2 ), 日本建築学会大会学術講演梗概集, pp.1407 $\sim 1410,1982.10$

13) 青山博之, 他 2 名：既存鉄筋コンクリート建物の耐震補強工法に関す る研究 (その 1 ), 日本建築学会大会学術講演梗概集, pp.81〜82, 1985.10

14) 緒方恭子, 壁谷澤寿海：曲げ降伏型鉄筋コンクリート耐震壁の変動シ アスパン加力実験, 第 6 回コンクリート工学年次講演会論文集, pp.717 $\sim 720,1984$

15) 杣木孝裕, 他 2 名: 厚壁型鉄筋コンクリート耐震壁の変動シアスパン 加力実験，第 7 回コンクリート工学年次講演会論文集，pp.369〜372, 1985

16) 壁谷澤寿海, 他 2 名 : 鉄筋コンクリート耐震壁の開口補強法に関する 実験的研究, コンクリート工学年次論文集, Vol.10, No.3, pp.409〜 141, 1988

17) 壁谷澤寿海, 他 2 名：高層耐震壁の耐力と変形能力に関する実験的研 究, Vol.9, No.2, pp.379 384, 1987

18) 福沢六郎, 他 8 名：建屋の復元力特性に関する研究（高配筋耐震壁に 関する実験, その 37〜 40), 日本建築学会大会学術講演梗概集, B 分冊, pp.847 854, 1985.10

19) 羽鳥敏明, 他 4 名：建屋の復元力特性に関する研究（高配筋耐震壁に 関する実験, その 59), 日本建築学会大会学術講演梗概集, B 分冊, pp. $1117 \sim 1118, \quad 1986.8$

20) 前田安治, 他 5 名 : 建屋の復元力特性に関する研究（高強度コンクリ 一トを用いた耐震壁に関する実験，その 62，63), 日本建築学会大会学 術講演梗概集， B 分冊, pp.1123 1126，1986.8

21) 東端泰夫, 他：曲げ，せん断，軸力を受ける鉄筋コンクリート耐震壁 に関する実験的研究 (その 1 , その 2 ), 日本建築学会大会学術講演梗 概集，pp.1189〜1192，1975.10

22) Oestertle,R.G., et al. : Web Crushing of Reinforced Concrete Structure Walls, ACI Journal, May-June, pp.231 241， 1984

23) 遠藤利根穂, 他：耐震壁による建築物の崩壊防止に関する研究, 昭和 46 年度建築研究所年報, pp.625 632, 1972

24) 片桐 徹, 他 2 名：背高な連層耐震壁の強度と変形, 日本建築学会大 会学術講演梗概集, C 分冊, pp.579 580, 1990.10
25) 斉藤文孝, 他 2 名：高強度コンクリートを用いた耐震壁のせん断破壊 性状に関する実験的研究, 日本建築学会大会学術講演梗概集, C 分冊, pp. $605 \sim 606,1990.10$

26) 金本清臣，他 2 名：高強度材料を用いた曲げ降伏型鉄筋コンクリート 耐震壁の復元力特性（その 1 , その 2 ), 日本建築学会大会学術講演梗 概集, C 分冊, pp.607〜 610，1990.10

27) 松本和行，他 2 名：シアスパン比の大きい高強度鉄筋コンクリート耐 震壁の静加力実験, コンクリート工学年次論文集, Vol.14, No.2, pp.819 $\sim 824,1992.6$

28) 熊谷仁志, 他 : 高強度コンクリートを用いた耐震壁のせん断特性（そ の 1 , その 2), 日本建築学会大会学術講演梗概集, $\mathrm{C}$ 分冊, pp.611〜 $612,1990.10$

29) 柳沢延房，他：高強度材料を用いた鉄筋コンクリート耐震壁のせん断 特性（その 1 , その 2 ), 日本建築学会大会学術講演梗概集, $\mathrm{C}$ 分冊, pp.346 350, 1992.8

30) 白石一郎，他 2 名：鉄筋コンクリート造耐震壁の最大耐力への壁筋の 効果，日本建築学会構造系論文報告集，第 392 号，pp.34～45, 1988.10

31) 長島俊雄, 他 2 名：高強度コンクリート（Fc600）を用いた耐震壁の力 学性状, コンクリート工学年次論文集, Vol.15, No.2, pp.1155〜1160, 1993

32) 菅野俊介, 他 2 名：高強度コンクリート而震壁の強度と変形性能に関 する実験的研究, 日本建築学会大会学術講演梗概集, C 分冊, pp.437 $\sim 438,1991.9$

33) 長沼一洋 : 鉄筋コンクリート耐震壁のせん断強度に関する解析的研究, 日本建築学会構造系論文集，第 447 号，pp.107～117，1993.5

34) 長沼一洋 : 鉄筋コンクリート連層耐震壁の設計法に関する研究 （そ の 1 ) 単層耐震壁のせん断強度算定法, 日本建築学会関東支部研究報 告集, pp.101 104, 1993

35) 長沼一洋 : 鉄筋コンクリート耐震壁の非線形解析手法とせん断強度に 関する研究，千葉大学学位論文， 1993

（2009年 4 月 20 日原稿受理，2009年 7 月 22 日採用決定） 